\title{
Spinout Formation: Do Opportunities and Constraints Benefit High Capital Founders?
}

\author{
by

\section{Natarajan Balasubramanian Syracuse University}

\author{
Mariko Sakakibara \\ University of California, Los Angeles
}

\section{CES 15-07 January, 2015}

The research program of the Center for Economic Studies (CES) produces a wide range of economic analyses to improve the statistical programs of the U.S. Census Bureau. Many of these analyses take the form of CES research papers. The papers have not undergone the review accorded Census Bureau publications and no endorsement should be inferred. Any opinions and conclusions expressed herein are those of the author(s) and do not necessarily represent the views of the U.S. Census Bureau. All results have been reviewed to ensure that no confidential information is disclosed. Republication in whole or part must be cleared with the authors.

To obtain information about the series, see www.census.gov/ces or contact Fariha Kamal, Editor, Discussion Papers, U.S. Census Bureau, Center for Economic Studies 2K132B, 4600 Silver Hill Road, Washington, DC 20233, CES.Papers.List@census.gov. 


\begin{abstract}
We examine the role of human capital in employees' decisions to leave their parent firms and form spinouts. Using a large sample of individuals who formed spinouts in manufacturing industries between 1992 and 2005, and their co-workers who did not, we find that after controlling for age, education level, gender and alien status, individuals with higher human capital (measured as their earnings or experience) are more likely to form spinouts. We then examine the impact of industry opportunities and constraints on the propensity of high human capital individuals to form spinouts. Counterintuitively, we find that both industry constraints (measured as industry capital intensity) and opportunities (industry R\&D intensity) reduce the propensity of higher human capital individuals to form spinouts. We interpret these results as being consistent with the argument that high human capital founders are more likely to choose larger, more capital-intensive projects than low human capital individuals, and thus face greater constraints. On the other side, R\&D intensive industries appear to present abundant entrepreneurial opportunities, allowing low human capital individuals to identify their own opportunities thus decreasing the relative advantage of high human capital individuals.
\end{abstract}




\section{INTRODUCTION}

It has been argued that spinouts — new firms founded by employees of established firms — performs better than other types of new ventures (Agarwal et al. 2004; Klepper 2007;

Chatterji, 2008; Klepper 2009). ${ }^{1}$ The success of spinouts is often attributed to the human capital that their founders developed at their employers before they established the spinouts. ${ }^{2}$ Measured in many different ways, human capital has been considered as a critical resource for the success of entrepreneurial firms (Keeley and Roure, 1990; Florin et al, 2003; Sexton and Upton, 1985; Unger et al, 2011). Moreover, the critical business experience and knowledge gained by spinout founders at their parent firms has been found to be important in determining spinout formation and success. For example, Bhide (2003) found that over $70 \%$ of new ventures categorized as the 100 fastest growing private companies had founders who said the ideas for the venture came from experiences and ideas that they gained while working at other companies.

\footnotetext{
${ }^{1}$ In entrepreneurship studies, the term "spinouts" and "spinoffs" are often used interchangeably (Klepper, 2009; Berchicci et al, 2011). In corporate finance, however, a spinoff is defined as a way in which a firm divests a division through the distribution of shares in this division to existing shareholders (Gertner et al. 2002). To avoid any confusion, we use the term "spinouts" throughout the paper.

${ }^{2}$ Hereinafter, such employers will be referred to as "parent firms" and the specific establishment that the founders worked at as the "parent firm establishment".
} 
However, past studies suggest that high human capital individuals don't necessarily leave their parent firms (more often than low human capital individuals) to form spinouts. On the one hand, if potential entrepreneurs have good business ideas, they can possibly earn more by starting a new company than staying with their parent firms and implementing their ideas with those firms (Anton and Yao, 1995). On the other hand, parent firms may offer higher wages and better career opportunities to high human capital individuals, so they might be motivated to stay (Stern, 2004). Reflecting these conflicting theoretical arguments, empirical evidence on whether high human capital individuals are more likely to be entrepreneurs or not has been mixed (Amit, Glosten and Muller, 1990; Amit, Muller and Cockburn, 1995; Evans and Leighton, 1989; Hamilton, 2000; Groysberg et al, 2007; Campbell et al, 2012).

More importantly, the relative propensity of high human capital individuals to form spinouts should critically depend on the industry conditions they operate in. Past studies have identified industry conditions which increase the likelihood that new firms have greater opportunities, such as the availability of risk capital (Cohen et al., 1987), limited importance of scale economies or first mover advantages (Shane and Venkataraman, 2000), and low reliance on complementary assets (Teece, 1986). What is less clear, however, is whether high human capital founders benefit more from these opportunities and constraints than low human capital individuals. For example, abundant entry opportunities in an industry might allow low human capital individuals to identify their own opportunities and thereby reduce the 'creative hurdle' for them to overcome. This, in turn, will decrease the relative advantage of high human capital individuals with regard to spinout formation. Similarly, the presence of constraints may affect high human capital and low human capital individuals differently depending on the type of new ventures started by them. More broadly, it appears that in order to develop a complete picture of 
spinout formation, we need to examine some of the industry conditions that may affect spinouts and investigate how these conditions differentially affect high human capital individuals' decision to form spinouts. However, to our knowledge, the relationship between such industry conditions and the human capital of founders has received limited attention.

In this study, we investigate the link between spinout formation and human capital, and the effect of industry conditions on the decision of employees to form spinouts using US Census Bureau micro-data. In particular, we make three contributions to the literature on spinout formation and the associated role of human capital. First, we study a broad cross-section of spinouts, specifically those formed in all manufacturing industries between 1992 and 2005, along with their founders and their co-workers. Past studies of spinouts have typically focused on a single industry (Unger et al, 2011), such as the disc drive industry (Agarwal et al, 2004) and lasers (Klepper and Sleeper, 2005). While single-industry studies can allow researchers to obtain detailed information on human capital, it is harder to generalize results from such studies. By focusing on a large set of industries, we seek to provide a broad characterization of the phenomenon, and thus fill a gap in the literature. ${ }^{3}$ Our second and more important contribution is to identify industry conditions where high human capital individuals are more likely to form spinouts. Given the dominance of single industry studies in the literature, this topic has not received much attention. Finally, while employer-employee matching data has been used for analysis of spinouts in countries such as Denmark and Brazil (Muendler et al., 2012; Dahl and Reichstein, n.d.), to our knowledge, this study is the first attempt to use US data for a

\footnotetext{
${ }^{3}$ It is also important to note that this broad characterization also comes at a cost: our study lacks the rich details of a single-industry study.
} 
comprehensive analysis that links industry characteristics and human capital of spinout founders. This is important since the U.S. is arguably one of the most entrepreneurially active countries in the world. Together, these contributions, we hope, expand the scope of our understanding of spinout formation process.

Our data cover individuals in 23 states of the U.S who formed spinouts between 1992 and 2005, matched to their coworkers at parent establishments two quarters prior to spinout formation. ${ }^{4}$ In total, our data cover over 2.2 million individual-quarter observations with information on their human capital characteristics (age, experience, education, etc.) as well as the industry characteristics of their parent establishments. Though the data cover a broad set of industries from SIC1 to SIC9, we focus on manufacturing (SIC2 and 3) due to the availability of more-detailed industry-level data.

We find that, after controlling for age, education level, gender and alien status, individuals with higher human capital, measured using their earnings and experience at the parent establishment are more likely to leave their parent firms to form spinouts. We then focus on three industry characteristics - capital intensity (constraint), human capital intensity (opportunity) and R\&D intensity (opportunity) - and examine whether they differentially affect high human capital individuals. We find that high human capital individuals are less likely to form spinouts in industries with high capital intensity and high R\&D intensity, while industry human capital intensity does not appear to be correlated with the propensity of high human capital individuals to form spinouts. Thus, our results suggest that (some types of) constraints

\footnotetext{
${ }^{4}$ Spinouts are identified using employee-movement data, and are broadly defined as "clusters" of 3 to 20 employees moving from an existing firm to form a "new firm".
} 
and opportunities may reduce the relative propensity of higher human capital individuals to form spinouts. These results are consistent with the hypothesis that high human capital founders are more likely to choose larger projects (than low human capital individuals), and thus face greater capital constraints. R\&D intensive industries, on the other hand, present numerous entrepreneurial opportunities for all individuals, which may permit lower human capital individuals to identify and explore their own opportunities, thereby decreasing the relative propensity of high human capital individuals to form spinouts.

Contrary to our expectation, we find no effect of industry human capital intensity on high human capital individuals' propensity to form spinouts. We interpret this as the likely result of two opposing forces that cancel each other. While human capital intensive industries present entrepreneurial opportunities to high human capital individuals, such industries might also require scale, scope, and complementary assets to commercialize ideas. These requirements may create advantages for incumbent over spinouts, thus discouraging high human capital individuals to form spinouts.

The rest of the paper is organized as follows. The next section develops the basic hypotheses of our paper. This is followed by a description of the data, empirics and variables. The subsequent section presents the results. The final section discusses and concludes.

\section{HUMAN CAPITAL, INDUSTRY CONDITIONS AND SPINOUT FORMATION Human Capital and Spinout Formation}

Individual human capital refers to all knowledge resident in the individual. At its broadest, human capital can be defined as the result of any investment in "activities that influence future real income [of people] through the imbedding of resources in people" (Becker, 1962; italics added). For purposes of new venture formation and management, some relevant individual 
human capital includes on-the-job training, problem-solving and opportunity-identification abilities, environmental and managerial knowledge, and networks.

Whether individuals with high human capital are more likely to engage in entrepreneurial activities is a subject of active debate. Overall, the evidence on whether low or high human capital individuals have higher propensities to form new firms (whether spinouts or otherwise) seems mixed. On one hand, the parent firms of potential entrepreneurs may be able to offer a higher wage or a better career opportunity than new firms and therefore may be able to attract and retain individuals with higher human capital (Stern, 2004). This is consistent with studies that find that those who transitioned to self-employment had relatively lower wages (Amit, Glosten and Muller, 1990; Amit, Muller and Cockburn, 1995; Evans and Leighton, 1989) or find little evidence for wage differences between would-be entrepreneurs and non-entrepreneurs (Hamilton, 2000). On the other hand, Groysberg et al (2007) finds that higher performing individuals become entrepreneurs at higher rates. Similarly, in a study of the legal services industry, Campbell et al. (2012) find that when higher-earning employees leave a firm, they are more likely to go to a new firm than to an incumbent firm.

Relative to other new firms, some arguments suggest that spinouts should have higher human capital. Founders of spinouts can develop their own human capital while they are employed at their parent firms and transfer it to their own firms (Klepper and Sleeper 2005). Through their employment, these founders can also obtain managerial experience (Dencker et al. 2009), technical knowledge (Agarwal et al. 2004), and familiarity with the regulatory environment (Chatterji 2009). Furthermore, their experience at an existing firm may also help them develop personal networks that could be used to obtain financing (Easley and Roberts 2006) and other resources for the new firm. That spinouts may have higher human capital is also 
consistent with Klepper (2007) who argues that disagreements with the parent firm were the main reason for the creation of many spinouts in the Detroit automobile industry.

In line with these two conflicting views regarding the relationship between the level of human capital of individuals and the propensity for spinout formation, we state a set of competing hypotheses.

Hla. High human capital individuals are more likely to leave and form spinouts than low human capital individuals.

H1b. High human capital individuals are less likely to leave and form spinouts than low human capital individuals.

\section{Industry Condition and Spinout Formation: The Effect of Human Capital}

It is well known that industry conditions affect the level of entry in an industry. Since the decision to form spinouts is essentially one of entry into the market, we should expect industry conditions to affect those decisions. Moreover, since high human capital individuals may start new ventures that are different from those started by those with lower levels of human capital, the effect of these conditions may not be uniform throughout the human capital distribution. In this section, we discuss how certain industry conditions can affect high and low human capital individuals differently. Throughout, when we refer to high and low human capital individuals, we are restricting the comparison of human capital to within an industry. Appendix 1 formalizes our intuition discussed in these paragraphs into a simple mathematical model.

\section{Capital Intensity}

Past studies suggest that incumbents may have advantages of scale, scope, tax, or information that allow them to commercialize a discovery made by employees more profitably than a new firm started by employees (Klepper, 2001; Helfat and Lieberman, 2002). 
Complementary assets of incumbent firms such as production, sales channel, and/or marketing capabilities may also be crucial to bring innovations to the market quickly and successfully (Teece, 1986). Along similar lines, findings in Hubbard (1998) suggest a disadvantage for spinouts that not only must rely more on external financing but also suffer from having a shorter credit history than incumbents. Incumbents on the other hand, can rely to a greater extent on funds generated from their operations, which puts them at an advantage when buying capital equipment (Schoonhoven et al, 1990). These arguments suggest that when the industry is capital intensive, potential spinout founders may find forming spinouts to be disadvantageous relative to staying with their parent establishments.

However, such a disadvantage should affect high human capital individuals more severely than low human capital individuals. This is because, for several reasons, individuals with higher human capital are more likely to choose larger, more capital-intensive projects. First, such individuals are likely to choose inherent better ideas that have a higher chance of being successful and growing into a larger firm (which is capital intensive). Second, individuals with higher human capital are more likely to have better managerial skills, which will allow them to manage larger operations more efficiently. Third, higher human capital individuals are more likely to be technologically skilled, which often implies the use of capital-intensive equipment and processes (over the use of labor-intensive processes). Therefore, the presence of capital constraints will be more binding on those that start larger ventures, or on those with higher human capital. Thus we hypothesize:

H2. The propensity of high human capital individuals to form spinouts (relative to low human capital individuals) declines with industry capital intensity.

\section{Human Capital Intensity}


Human capital intensity can be broadly defined as the importance of human capital in an industry, or more specifically, as the importance of tacit knowledge and ideas imbedded in the people in determining firm performance in that industry. Individuals with higher human capital are more likely to start spinouts in such industries. First, the higher importance of human capital in determining firm success provides an inherent advantage to those that possess such capital. Second, since elements of human capital such as knowledge, ideas and skills are tacit and imbedded in people, it is relatively easy for individuals to bring their human capital to their new ventures. Furthermore, employees often regard their job at incumbents as an apprenticeship to start their own firms (Franco and Filson 2006); human capital-intensive industries may provide learning opportunities for such potential spinout founders, especially for those who have high human capital. Such industries are also more likely to present greater difficulties for incumbents to contract with their employees to reveal their ideas (Anton and Yao 1995). Finally, it is likely that these industries offer better options (outside existing firms) for potential new firm founders. If so, arguments in studies such as Cabral and Wang (2008), Klepper and Thompson (2007) and Klepper (2007) (that incumbents often fail to recognize good ideas their employees generate) imply that individuals with high human capital may find that forming spinouts to be a better alternative than staying with their parent firms. ${ }^{5}$ Thus, we hypothesize:

\footnotetext{
${ }^{5}$ An opposing argument can be made as follows. To the extent that such knowledge and ideas need scale, scope, and complementary assets to be commercialized, established firms have an advantage. Furthermore, established firms can attract more talent than new firms because they can offer better pay, job security, prestige, and opportunities to pursue what the researchers want
} 
H3. The propensity of high human capital individuals to form spinouts (relative to low human capital individuals) increases with industry human capital intensity.

\section{Technological Intensity}

Studies have argued that incumbents have a disadvantage when it comes to competencedestroying innovations (Tushman and Anderson, 1986; Henderson and Clark, 1990). Rapidly changing technologies reduce the relevance of any prior knowledge of incumbents. Such environments seem to exacerbate the problem of "organizational inertia" (Balasubramanian and Lee, 2008), which puts incumbents at a disadvantage. Further, theoretical models in Wiggins (1995) and Anton and Yao (1995) suggest that innovations commercialized by spinouts are more likely to open new submarkets or break new paths. Since opportunities for such innovations are likely to be higher in technologically intensive industries, their conjectures imply that spinouts may show greater success than incumbents, and hence are more likely to occur in such industries. However, the increased presence of such opportunities applies to both high and low human capital individuals. Unlike in industries with fewer opportunities, low human capital individuals might be more easily able to identify 'good' opportunities, thus decreasing the relative advantage of high human capital individuals. Thus, we hypothesize:

H4. The propensity of high human capital individuals to form spinouts (relative to low human capital individuals) declines with industry technological intensity.

Figure 1 presents a visual summary of Hypotheses $\mathrm{H} 2$ and $\mathrm{H} 4$ (note that the hypothesized effect of $\mathrm{H} 3$ is similar to that of $\mathrm{H} 2$ ).

(Stern 2004). These arguments suggest that in human capital intensive industries, the propensity to form spinout is low. 


\section{DATA, EMPIRICS AND VARIABLES}

The primary data for the study come from the "Longitudinal Employer Household Dynamics" (LEHD), a composite matched employer-employee dataset comprising multiple state-level databases maintained by the U.S. Census Bureau. This dataset, created under the LEHD program, is maintained by the U.S. Census Bureau with contribution from the various individual participating states. The two relevant databases within the LEHD are (a) the "Employment History File" (EHF), which provides the employment history of all individuals that work in establishments in states that participate in this program and (b) the "Employer Characteristics File" (ECF) which contains information on all employers (i.e. establishments) in states that participate in this program. ${ }^{6}$ These databases, maintained separately for each participating state, contain quarterly information on employment and payroll for the establishment, and wage information for the individual. In particular, for each individual, for each quarter, the database provides the payroll they obtained from each firm they worked for (identified by the "State Employer Identification Number" or the SEIN). ${ }^{7}$ The LEHD does not contain information on revenues or on any other expenditure. 1991 is the first year the LEHD data are available for at least 3 states. ${ }^{8}$ The geographical coverage of the data increases over time as more states begin to participate in this program.

\footnotetext{
${ }^{6}$ As of 2005 , there were 23 states participating in this program.

${ }^{7}$ Note that individuals can simultaneously work for more than one firm in any given quarter.

${ }^{8}$ Census confidentiality requirements prohibit disclosure of state-specific information. Public disclosure of LEHD information requires that any disclosed data cover at least 3 states.
} 


\section{Identification of spinouts}

The identification of spinouts was based on employee-movement data from the LEHD. We began by identifying clusters of employees moving from one establishment ('the predecessor establishment') to another ('the successor establishment') within the same state during a 2quarter period. ${ }^{9}$ Of these clusters, we restricted our attention to clusters that had between 3 and 20 employees as potential spinouts.

From these clusters, we excluded clusters where the predecessor establishment was too small relative to cluster size (specifically, we imposed a condition that the cluster size be at most $50 \%$ of employment at the predecessor establishment) and clusters where the successor establishment was too large relative to cluster size (specifically, we imposed a condition that the cluster size be at least $80 \%$ of employment at the successor establishment). ${ }^{10}$ These conditions were aimed at reducing the likelihood of simple ownership changes being identified as spinouts. We also excluded clusters where the successor establishment was more than one year old at the

\footnotetext{
${ }^{9}$ In particular, we adopted the following algorithm to identify this list. From the LEHD, for each individual, for each quarter, we identified the list of all SEINs that that individual obtained a positive pay from. For each individual, for each quarter ("the successor quarter"), we then compared the list of SEINs with the list of SEINs from two quarters ago ("the predecessor quarter"). Any individual with an SEIN in the successor quarter that is not in the list of SEINs from the predecessor quarter was classified as a potential candidate for founding a spinoff. Individuals who shared the same predecessor establishment (in the predecessor quarter) and the same successor establishment (in the successor quarter) were combined into a "cluster".

${ }^{10}$ Cluster size was defined as the number of individuals in the cluster.
} 
time of the employees moving to the establishment. In principle then, these clusters represent groups of employees moving from an existing firm to join a new venture. Since the LEHD is a state-level dataset, it is possible that a single establishment in a state that is classified as a new venture may actually belong to a firm that has establishments in multiple states (and hence, is not a spinout). Hence, the preliminary list of spinouts was then refined by using data from the LBD (another micro dataset at the Census Bureau) to exclude any such establishments. Establishments in the resulting list were treated as spinouts. ${ }^{11}$ We then eliminated any spinouts that did not have all the variables we were interested in. The resulting sample had about 29,100 spinouts. ${ }^{12}$

For each of these spinouts, we then identified the "founders" as the initial cluster of employees who moved from the parent establishment. To create our sample, we appended to this list of spinout founders, all their co-workers at the parent establishment two quarters prior to the formation of the spinout. Finally, we limited our analysis to manufacturing given the availability of measures of industry characteristics. Together, this resulted in about 2.5 million individualquarter observations.

Dependent Variable The dependent variable in all our regressions is a dummy variable that is 1 if the individual founded a spinout and 0 if they did not.

\footnotetext{
${ }^{11}$ Note that spinoffs defined here include both employee startups (i.e. involuntary spinoffs or entrepreneurial spinoffs) and corporate-sponsored spinoffs (i.e. voluntary spinoffs or parent spinoffs). We do not have data on how these new ventures are financed, so we cannot separate these two types.

${ }^{12}$ In order to reduce the level of disclosure risk to the US Census Bureau, the number of observations has been rounded to the nearest 100 .
} 


\section{Independent Variables}

All our independent variables are measured at two quarters before the formation of the spinout. We use three primary human capital variables including earnings, industry experience and experience at the parent establishment. Given their skewed distributions, we use the logarithmic transformation of all human capital variables.

Log earnings. Earnings are measured as the quarterly earnings of the employee.

Log industry experience. This is measured as the number of quarters of experience in the SIC3 industry of the parent establishment, depreciated at the rate of $15 \%$.

Log parent establishment experience. This is measured as the number of quarters that the employee received positive earnings at the parent establishment.

Our next set of variables were employee-level controls, all measured at two quarters before spinout formation.

Log age. This is the logarithm of the age of the employee in quarters.

Log imputed education. This is the number of years of education imputed to the individual by the Census Bureau.

Gender. This is a dummy variable indicating gender. Alien: This is a dummy variable indicating whether the individual is a US citizen or not. Our explanatory variables were industry characteristics and their interactions with human capital, all measured at two quarters before spinout formation 
Log Industry Capital Intensity: This was defined as the (log of) ratio of total industry capital expenditure to total industry employment. ${ }^{13}$ These data were obtained from publicly available data on the Annual Survey of Manufactures.

Log Industry $R \& D$ Intensity: This was defined as the log of one plus the ratio of total industry $R \& D$ expenditure to total industry sales. These data were obtained from Compustat.

Industry Human Capital Intensity: This was defined as the average wage in the industry, and was based on the Annual Survey of Manufactures.

Finally, the tacit nature of learning-by-doing has been found to lend incumbents with a significant performance advantage (Balasubramanian, 2011). So, we included interactions of individual human capital measures with Industry Learning Intensity as a control. These intensities were obtained from Balasubramanian and Lieberman (2010).

\section{Empirics}

We begin our empirical analysis with the following specification:

$$
D_{i j p t}=F_{E A R N_{i}}+\text { FINDEXP }_{i}+F A G E_{i}+F E D U_{i}+F_{A L I E N}+F G E N D E R_{i}+\left[\vartheta_{j}\right]+
$$

$\left[\delta_{t}\right]+\left[\gamma_{j t}\right]+\left[\rho_{p t}\right]+\epsilon_{i j p t}$

where:

FEARN is the (log) individual's earnings two quarters before the new venture formation, FINDEXP is the (log) individual's industry experience (in the industry of the parent establishment) two quarters before the new venture formation,

\footnotetext{
${ }^{13}$ As an alternative, we used the ratio of industry-level perpetual inventory stocks to total industry employment as a measure of industry capital intensity, and found the two measures to be highly correlated (spearman's rho $>90 \%$ ).
} 
FAGE is the (log) individual's age at two quarters before the new venture formation,

FEDU is the (log) individual's years of education as imputed by the US Census Bureau,

FALIEN is an indicator of whether the founder is an alien in the US,

FGENDER is an indicator of the founder's gender,

$\vartheta_{\mathrm{j}}$ are industry fixed effects,

$\delta_{\mathrm{t}}$ are year fixed effects,

$\gamma_{\mathrm{jt}}$ are joint SIC3-year fixed effects, and

$\rho_{\mathrm{pt}}$ are joint parent establishment-year-quarter fixed effects.

The square brackets around the fixed effects indicate that these fixed effects are entered one set at a time. Of these variables, due to Census Bureau disclosure restrictions, we do not present coefficients on FALIEN and FGENDER. However, the coefficients on these variables were always small and statistically insignificant.

Since the dependent variable is a dummy variable, the preferred specification is a logit (or probit) regression. However, with over 2 million observations, we were not able to obtain convergence (within a reasonable number of days of running the code) on many of our specifications, especially those that included high dimensional fixed effects. Therefore, we present OLS results on these specifications. As robustness checks, we estimated both OLS and logit regressions for one of the specifications and obtained very similar results. Further, we also estimated logit regressions using a random sample of coworker samples, and obtained very similar results to the corresponding OLS specifications.

To test the role of industry characteristics, we augmented Equation 1 as follows:

$$
\begin{gathered}
D_{i j p t}=F E A R N_{i}+F_{I N D E X P_{i}}+F A G E_{i}+F E D U_{i}+F A L I E N_{i}+F G E N D E R_{i}+ \\
\text { h. } K_{j t}+h . R_{j t}+h . H_{j}+h . \lambda_{j}+\left[\gamma_{j t}\right]+\left[\rho_{p t}\right]+\epsilon_{i j p t}
\end{gathered}
$$


where:

$h$ is a measure of human capital,

$K_{j t}$ is industry capital intensity,

$R_{j t}$ is industry R\&D intensity,

$H_{j}$ is industry human capital intensity,

$\lambda_{j}$ is industry learning intensity, and

h. $C$ denotes the interaction of the human capital measure and industry characteristic $C$.

Note that we have not included any of the industry characteristics directly since their direct

effects will be subsumed within the fixed effects. As discussed earlier in this section, we use three different measures of individual human capital: earnings, industry experience and experience at the parent firm.

\section{RESULTS}

Table 1 presents the results of estimating Equation 1. Model 1 includes separate industry and year effects. The coefficient on earnings is strongly positive, suggesting that individuals with higher human capital are more likely to form spinouts. However, none of our other measures of human capital are significant. Model 2 includes joint industry-year fixed effects, thus using only the variation within an industry-year to estimate the coefficients. The coefficient on earnings nearly doubles in magnitude (compared to Model 1) and is still positive and significant. However, the coefficient on parent firm experience also turns significantly positive though the magnitude is similar to that in Model 1. Model 3 includes joint parent establishment-year-quarter fixed effects. Thus, this provides a very narrow and conservative comparison, limited to individuals at a parent establishment in a given year and quarter. The results are similar to those in Models 1 and 2. 
Earnings and experience at the parent firm are strongly positive. Parent industry experience is not significant in any of the models. Age appears to be negatively and education positively related to the probability of founding a spinout but the coefficients are significant only in Model 3. Finally, as a robustness check, Model 4 uses logit regressions similar to Model 1 (i.e., they include separate industry and year effects). These results are virtually the same as in Model 1 suggesting that the choice of the regression method is not influencing our results.

Table 2 examines the impact of industry characteristics. We present the results of three models, each with a different measure of human capital. Throughout, we include parent establishment-year-quarter fixed effects. The coefficient on the interaction with industry capital intensity is strongly negative in all three models. This strongly supports Hypothesis 2 , and indicates that the relative propensity of high human capital individuals to form spinouts decreases as industry human capital increases. We do not find any support for Hypothesis 3; the coefficients on the interactions with industry human capital intensity are always insignificant. Finally, in line with Hypothesis 4, R\&D intensity also has a strong negative impact on the relative propensity of high human capital individuals to form spinouts. Thus, our results also strongly support for Hypothesis 4. Finally, the coefficients on learning intensity are negative but statistically insignificant.

Table 3 presents the same specifications as in Table 2 but includes less conservative joint industry-year fixed effects. The results are very similar to those in Table 2. We find strong support for Hypotheses 2 and 4 but there is no support for Hypothesis 3. Together, our results strongly suggest that both industry capital intensity and technological intensity reduce the relative propensity of high human capital individuals to form spinouts. 


\section{DISCUSSION AND CONCLUSION}

Spinouts are a particularly interesting and important form of entrepreneurial ventures. They appear to perform better than other types of new firms, and have been the subject of many studies. However, the empirical results on who forms a spinout - high human capital individuals or low human capital individuals - are mixed. In this study, we seek to shed more light on this by focusing on a large sample of spinouts across several industries and by examining whether the industry context makes a difference to the propensity of forming a spinout.

Our first result suggests that, on average, the propensity to form spinouts increases with the level of individual human capital. Two of our three measures of human capital - earnings and experience at the parent firm - are positively and significantly correlated with the probability of founding spinout. Based on the results in Model 3 (Table 1), a 10\% increase in individual earnings increases the probability of forming a spinout by about $4 \times 10^{-4}$. This translates to an economically significant $8 \%$ increase over the mean probability of forming a spinout (in our sample, about $5 \times 10^{-3}$ ). Thus, these results add to the empirical evidence on the relationship between individual human capital and entrepreneurship.

Our next set of results is somewhat counterintuitive. Normally, one would expect constraints and opportunities to work in opposite directions. However, it appears that both constraints and opportunities reduce the relative advantage of high human capital individuals. Consistent with our hypotheses, we find that the propensity of high human capital individuals (relative to those with lower human capital) to form spinouts is lower in industries with higher capital and R\&D intensity. While capital intensity lowers the propensity to lower spinouts for all individuals, it appears to have a higher effect on those with higher human capital. This is consistent with the argument that individuals with higher human capital are likely to start larger 
spinouts that require greater amounts of capital, and are this more likely to face capital constraints. Combined with the (likely) greater value of their outside options, industry contexts with higher capital constraints reduce the relative propensity of high human capital individuals to form spinouts. The effect of technological intensity is in the same direction as that of capital intensity. It is generally accepted that technological active industries offer more opportunities for entrepreneurial ventures. However, lower human capital individuals appear to benefit (relatively) more from the presence of opportunities.

Our regression results though economically and statistically significant do not allow us to disentangle the different mechanisms underlying the role of industry capital intensity and industry R\&D intensity. Our hypotheses (and model) predict that in the former, the interaction coefficients will be negative because higher human capital individuals will be less likely to form spinouts. In the latter case, the negative interaction coefficient arises because lower human capital individuals will be more likely to form spinouts. Hence, we plotted two graphs of the probability of founding a spinout on (log) earnings, one comparing capital intensive with noncapital-intensive industries, and one comparing $R \& D$ intensive to non- $R \& D$ intensive industries. ${ }^{14}$ We do not present the graphs due to increased administrative constraints on the disclosure of graphs, and instead describe them briefly. In the first case, as predicted, for low levels of earnings, the probability of founding is not very different between capital intensive and non- capital-intensive industries. However, as the level of earnings increases, the probability of founding increases much more in industries that are not capital intensive. Thus, capital constraints appear to differentially affect higher human capital individuals more than lower human capital individuals. In the second case, the graph for the non-R\&D intensive industries

${ }^{14}$ These were defined as industries in the top and bottom quartile of the intensities. 
has a higher slope (as predicted) but that is because it starts well below the line for R\&Dintensive industries, and eventually becomes higher. This is consistent with the argument that R\&D intensity appears to help individuals with lower human capital. ${ }^{15}$

Our results do not suggest a strong effect of industry human capital intensity on the probability of founding a spinout. While this requires further study with perhaps more finegrained measures, one possible explanation is that the advantage of incumbent firms in such industries might overwhelm potential opportunities for high human capital industries. Similarly, we do not find any effect of industry learning intensity though it should be noted that we only have time-invariant measures for this characteristic.

As with all studies, this one comes with several limitations. First, our study lacks the rich detail in individual industry studies. However, we hope that the sacrifice we have made in detail is compensated for by the gains in the breadth of our findings. Next, our measures of individual education are limited to the (imputed) number of years of education. Clearly, that does not reflect the significant variation in the subject (and quality) of education received by individuals. Further, we focused on the three most important characteristics. Perhaps there are other characteristics that influence the propensity to form spinouts. Finally, this study focuses only on the formation of spinouts, and not on their subsequent performance. A more complete picture requires that we also examine the short-term and long-term performance of the spinouts. Addressing some of these limitations could be the topic of future studies.

\footnotetext{
${ }^{15}$ Recall that our comparisons of high and low human capital are restricted to the same industry. Thus, it is entirely possible that on an absolute scale, R\&D intensive industries have higher levels of human capital than non-R\&D intensive industries.
} 


\section{REFERENCES}

Agarwal R, Echambadi R, Franco AM, Sarkar MB. 2004. Knowledge Transfer through Inheritance: Spin-out Generation, Development, and Survival. Academy of Management Journal 47(4): 501-522

Amit R, Glosten L, Muller E. 1990. Entrepreneurial Ability, Venture Investments and Risk Sharing. Management Science 36(10): 1232-1245

Amit R, Muller E, Cockburn I. 1995. Opportunity Costs and Entrepreneurial Activity. Journal of Business Venturing 10(2): 95

Anton JJ, Yao DA. 1995. Start-ups, Spin-offs, and Internal Projects. Journal of Law, Economics \& Organization 11(2): 362

Balasubramanian N, Lee J. 2008. Firm Age and Innovation. Industrial \& Corporate Change 17(5): 1019-1047

Balasubramanian N, Lieberman M. 2010. Industry learning environments and the heterogeneity of firm performance. Strategic Management Journal 31: 390-412.

Balasubramanian N., 2011. New Plant Venture Performance Differences among Incumbent, Diversifying, and Entrepreneurial Firms: The Impact of Industry Learning Intensity. Management Science. 57(3): 549-565

Becker GS. 1962. Investment in Human Capital: A Theoretical Analysis. Journal of Political Economy 70(5): 9-49

Berchicci L, King A, Tucci CL. 2011. Does the Apple Always Fall Close to the Tree? The Geographical Proximity Choice of Spin-outs. Strategic Entrepreneurship Journal 5(2): 120136 
Bhide AV. 2003. The Origin and Evolution of New Businesses. Oxford University Press:

New York

Cabral LMB, Wang Z. 2008. Spin-offs: Theory and Evidence from the Early U.S. Automobile Industry Federal Reserve Bank of Kansas City Working Paper:

Campbell BA, Ganco M, Franco AM, Agarwal R. 2012. Who Leaves, Where to, and Why Worry? Employee Mobility, Entrepreneurship and Effects on Source Firm Performance. Strategic Management Journal 33(1): 65-87

Chatterji AK. 2009. Spawned with a Silver Spoon? Entrepreneurial Performance and Innovation in the Medical Device Industry. Strategic Management Journal 30(2): 185-206

Cohen WM, Levin RC, Mowery DC. 1987. Firm Size and R\&D Intensity: A Reexamination. Journal of Industrial Economics 35(4): 543

Dahl MS, Reichstein T. n.d. Heritage of Employee Startups: Founder Experiences and Survival of New Firms, Working Paper:

Dencker JC, Gruber M, Shah SK. 2009. Pre-Entry Knowledge, Learning, and the Survival of New Firms. Organization Science 20(3): 516-537

Eesley CE, Roberts EB. 2006. Cutting Your Teeth: Learning from Rare Experiences, SSRN eLibrary:

Evans DS, Leighton LS. 1989. Some Empirical Aspects of Entrepreneurship. American Economic Review 79(3): 519

Florin J, Lubatkin M, Schulze W. 2003. A Social Capital Model of High-Growth Ventures. Academy of Management Journal 46(3): 374-384

Franco AM, Filson D. 2006. Spin-outs: Knowledge Diffusion through Employee Mobility. RAND Journal of Economics 37(4): 841-860 
Gertner R, Powers E, Scharfstein D. 2002. Learning about Internal Capital Markets from Corporate Spin-offs. The Journal of Finance 57(6): 2479-2506

Groysberg B, Nanda A, Prats MJ. 2009. Does Individual Performance Affect Entrepreneurial Mobility? Empirical Evidence from the Financial Analysis Market. Journal of Financial Transformation 25: 95-106

Hamilton BH. 2000. Does Entrepreneurship Pay? An Empirical Analysis of the Returns to Self-Employment. Journal of Political Economy 108(3): 604

Helfat CE, Lieberman MB. 2002. The Birth of Capabilities: Market Entry and the Importance of Pre-history. Industrial \& Corporate Change 11(4): 725-760

Henderson RM, Clark KB. 1990. Architectural Innovation: The Reconfiguration of Existing Product Technologies and the Failure of Established Firms. Administrative Science Quarterly 35(1): 9-30

Hubbard RG. 1998. Capital-Market Imperfections and Investment. Journal of Economic Literature 36(1): 193-225

Keeley RH, Roure JB. 1990. Management, Strategy, and Industry Structure: As Influences on the Success of New Firms: A Structural Model. Management Science 36(10): $1256-1267$

Klepper S. 2001. Employee Startups in High-Tech Industries. Industrial \& Corporate Change 10(3): 639-674

Klepper S. 2007. Disagreements, Spinouts, and the Evolution of Detroit as the Capital of the U.S. Automobile Industry. Management Science 53(4): 616-631

Klepper S. 2009. Spinouts: A Review and Synthesis. European Management Review 6(3): 159-171 
Klepper S, Sleeper S. 2005. Entry by Spinouts. Management Science 51(8): 1291-1306

Klepper S, Thompson P. 2007. Who Founds the Best Firms and Why? Intra-industry Spinouts and Disagreements, Working Paper:

Muendler M-A, Rauch JE, Tocoian O. 2012. Employee Spinouts and Other Entrants: Stylized Facts from Brazil. International Journal of Industrial Organization 30(5): 447-458

Schoonhoven CB, Eisenhardt KM, Lyman K. 1990. Speeding Products to Market:

Waiting Time to First Product Introduction in New Firms. Administrative Science Quarterly 35(1): 177-207

Sexton DL, Bowman N. 1985. The Entrepreneur: A Capable Executive and More. Journal of Business Venturing 1(1): 129-140

Shane S, Venkataraman S. 2000. The Promise of Entrepreneurship as a Field of Research. Academy of Management Review 25(1): 217-226

Stern S. 2004. Do Scientists Pay to Be Scientists? Management Science 50(6): 835-853

Teece DJ. 1986. Profiting from Technological Innovation: Implications for Integration, Collaboration, Licensing and Public Policy. Research Policy 15(6): 285-305

Tushman ML, Anderson P. 1986. Technological Discontinuities and Organizational Environments. Administrative Science Quarterly 31(3): 439

Unger JM, Rauch A, Frese M, Rosenbusch N. 2011. Human Capital and Entrepreneurial Esuccess: A Meta-Analytical Review. Journal of Business Venturing 26(3): 341-358

Wiggins SN. 1995. Entrepreneurial Enterprises, Endogenous Ownership and the Limits to Firm Size. Economic Inquiry 33(1): 54 
FIGURE 1: SPINOUT FORMATION AND HUMAN CAPITAL: INDUSTRY OPPORTUNITIES AND CONSTRAINTS

Hypothesis H1a is true

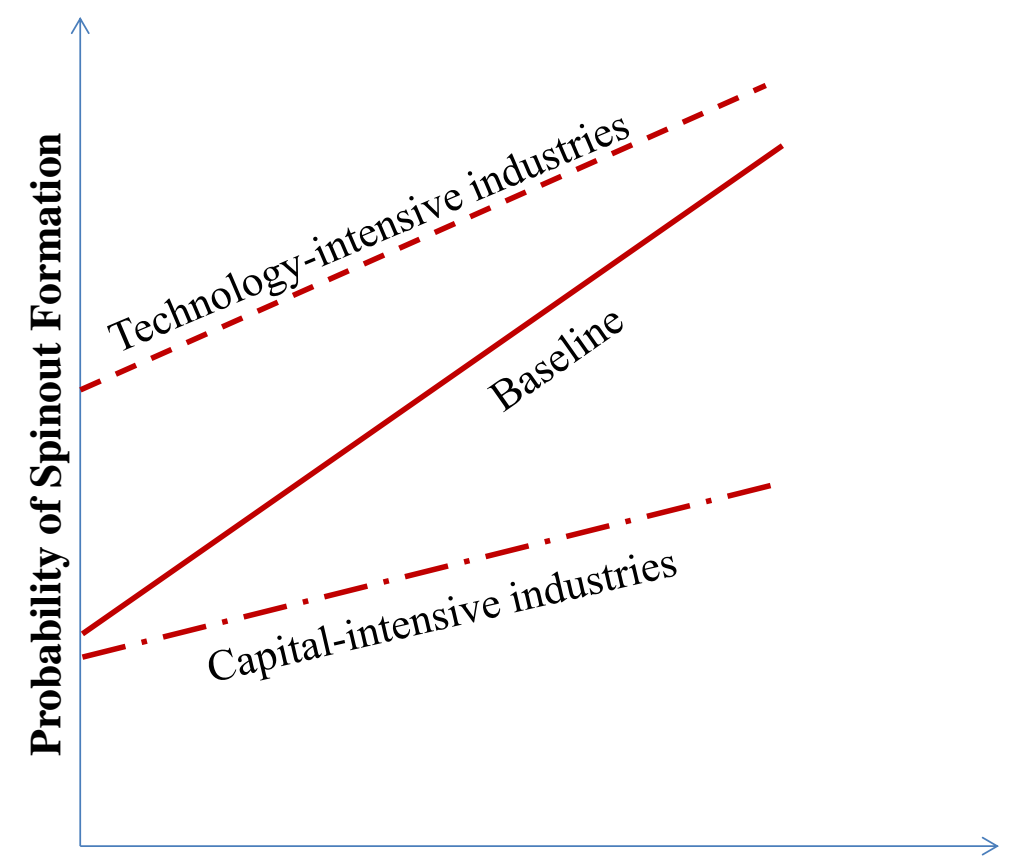

Individual Human Capital
Hypothesis H1b is true

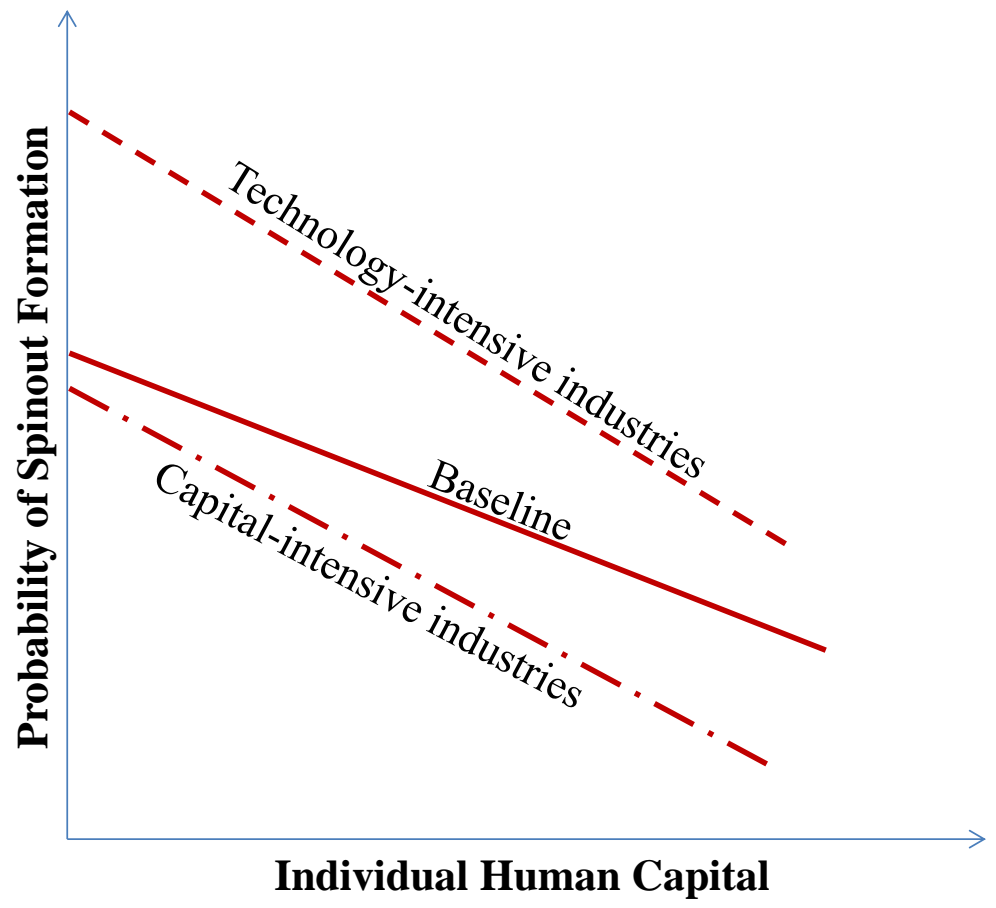


TABLE 1: COMPARISON OF SPINOUT FOUNDERS AND THEIR CO-WORKERS

\begin{tabular}{|c|c|c|c|c|}
\hline Model & 1 & 2 & 3 & 4 \\
\hline & OLS & OLS & OLS & Logit \\
\hline \multicolumn{5}{|l|}{ Founder Variables } \\
\hline \multirow[t]{2}{*}{ Log Earnings } & $0.00128 * * *$ & $0.00221 * * *$ & $0.00391 * * *$ & $0.183 * * *$ \\
\hline & $(0.00027)$ & $(0.00035)$ & $(0.00063)$ & $(0.028)$ \\
\hline \multirow[t]{2}{*}{ Log Parent Industry Experience } & -0.000685 & -0.000889 & 0.000184 & -0.0242 \\
\hline & $(0.00101)$ & $(0.000684)$ & $(0.000707)$ & $(0.101)$ \\
\hline \multirow[t]{2}{*}{ Log Experience at Parent Firm } & 0.000905 & $0.00103 * * *$ & $0.000799 * *$ & 0.0565 \\
\hline & $(0.00055)$ & $(0.00035)$ & $(0.000359)$ & $(0.0514)$ \\
\hline \multirow[t]{2}{*}{ Log Age } & -0.00055 & -0.000403 & $-0.00129 * * *$ & -0.0569 \\
\hline & $(0.000447)$ & $(0.000368)$ & $(0.000398)$ & $(0.0487)$ \\
\hline \multirow[t]{2}{*}{ Log Education } & -0.000362 & 0.00000959 & $0.000766^{* *}$ & -0.033 \\
\hline & $(0.000322)$ & $(0.000301)$ & $(0.000324)$ & $(0.0373)$ \\
\hline SIC3 and Year Fixed Effects & $\mathrm{Y}$ & & & $\mathrm{Y}$ \\
\hline SIC3-Year Fixed Effects & & $\mathrm{Y}$ & & \\
\hline Parent Estab-Year-Quarter Fixed & & & $\mathrm{Y}$ & \\
\hline \multicolumn{5}{|l|}{ Effects } \\
\hline $\mathrm{N}$ & $2,204,800$ & $2,204,800$ & $2,204,800$ & $2,204,800$ \\
\hline $\mathrm{R}^{2}$ & 0.026 & 0.064 & 0.143 & \\
\hline F-statistic & 3.482 & 6.806 & 7.099 & \\
\hline Log Likelihood & & & & -73222 \\
\hline Pseudo-R2 & & & & 0.177 \\
\hline
\end{tabular}


TABLE 2: IMPACT OF INDUSTRY CHARACTERISTICS

(OLS Regression with Parent Establishment-Year-Quarter fixed effects)

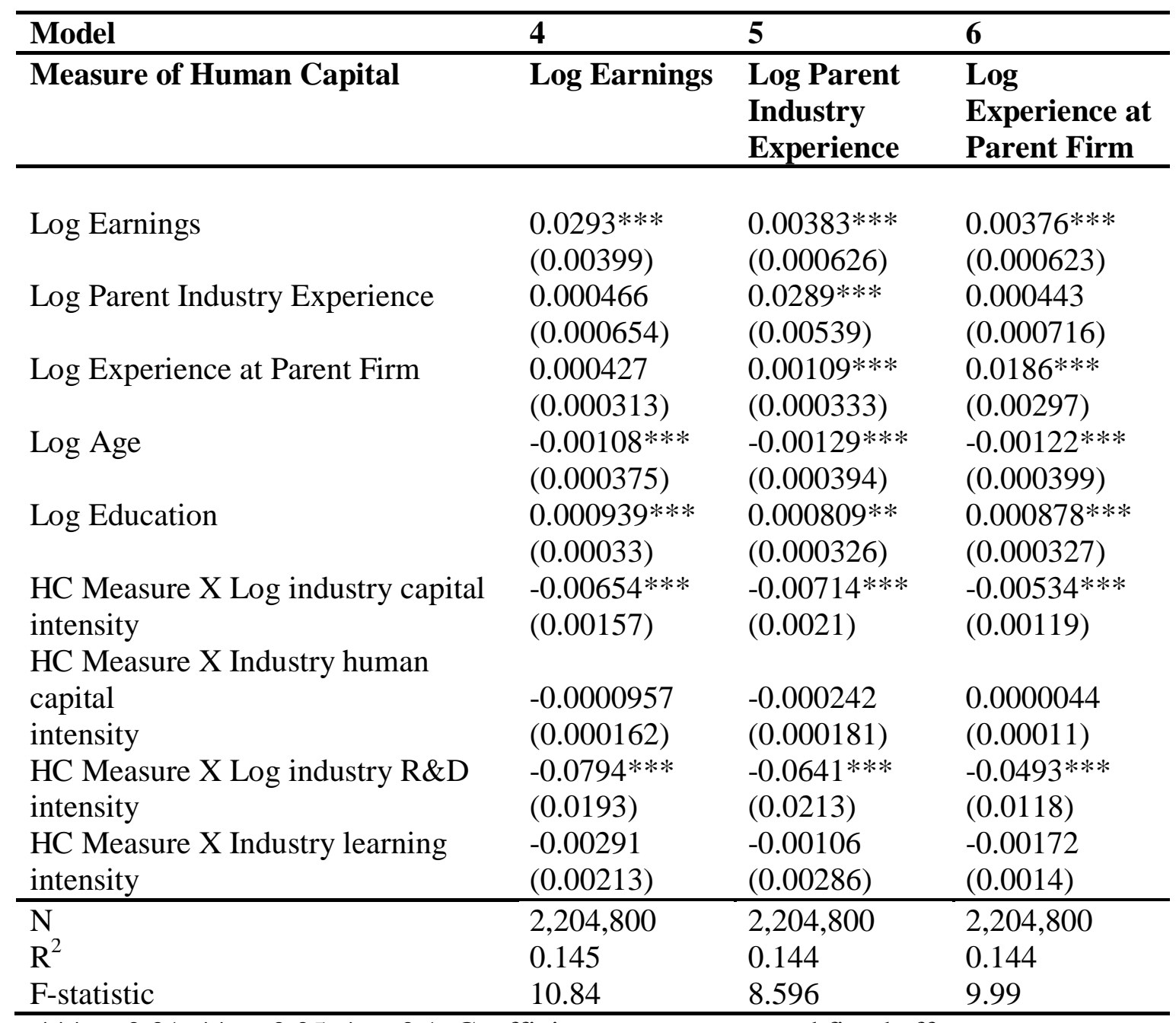

$* * * \mathrm{p}<0.01, * * \mathrm{p}<0.05, * \mathrm{p}<0.1$. Coefficients on constant and fixed effects not presented. Standard errors clustered at the venture level. F-statistics of model-fit are significant at or below the $0.01 \%$ level. 


\section{TABLE 3: IMPACT OF INDUSTRY CHARACTERISTICS}

(OLS Regression with SIC3-Year fixed effects)

\begin{tabular}{|c|c|c|c|}
\hline Model & 7 & 8 & 9 \\
\hline Measure of Human Capital & Log Earnings & $\begin{array}{l}\text { Log Parent } \\
\text { Industry } \\
\text { Experience }\end{array}$ & $\begin{array}{l}\text { Log } \\
\text { Experience at } \\
\text { Parent Firm } \\
\end{array}$ \\
\hline Log Earnings & $\begin{array}{l}0.0203 * * * \\
(0.00281)\end{array}$ & $\begin{array}{l}0.00212 * * * \\
(0.000344)\end{array}$ & $\begin{array}{l}0.00205^{* * *} * \\
(0.00034)\end{array}$ \\
\hline Log Parent Industry Experience & $\begin{array}{l}-0.00081 \\
(0.000675)\end{array}$ & $\begin{array}{l}0.0252 * * * \\
(0.00553)\end{array}$ & $\begin{array}{l}-0.000878 \\
(0.000728)\end{array}$ \\
\hline Log Experience at Parent Firm & $\begin{array}{l}0.000782 * * \\
(0.000334)\end{array}$ & $\begin{array}{l}0.00120 * * * \\
(0.000348)\end{array}$ & $\begin{array}{l}0.0173 * * * \\
(0.00289)\end{array}$ \\
\hline Log Age & $\begin{array}{l}-0.000289 \\
(0.00036)\end{array}$ & $\begin{array}{l}-0.000367 \\
(0.000368)\end{array}$ & $\begin{array}{l}-0.000288 \\
(0.000368)\end{array}$ \\
\hline Log Education & $\begin{array}{l}0.000141 \\
(0.000302)\end{array}$ & $\begin{array}{l}0.0000516 \\
(0.000302)\end{array}$ & $\begin{array}{l}0.000105 \\
(0.000302)\end{array}$ \\
\hline $\begin{array}{l}\text { HC Measure X Log Industry capital } \\
\text { intensity }\end{array}$ & $\begin{array}{l}-0.00510 * * * \\
(0.00111)\end{array}$ & $\begin{array}{l}-0.00764 * * * \\
(0.00213)\end{array}$ & $\begin{array}{l}-0.00535^{* * * *} \\
(0.0011)\end{array}$ \\
\hline $\begin{array}{l}\text { HC Measure X Industry human } \\
\text { capital } \\
\text { intensity }\end{array}$ & $\begin{array}{l}0.0000181 \\
(0.000096)\end{array}$ & $\begin{array}{l}-0.000121 \\
(0.000189)\end{array}$ & $\begin{array}{l}0.0000485 \\
(0.000092)\end{array}$ \\
\hline $\begin{array}{l}\text { HC Measure X Log Industry R\&D } \\
\text { intensity } \\
\text { HC Measure X Industry learning } \\
\text { intensity }\end{array}$ & $\begin{array}{l}-0.0740 * * * \\
(0.0112) \\
-0.00198 \\
(0.00122) \\
\end{array}$ & $\begin{array}{l}-0.0795 * * * \\
(0.0239) \\
0.00523^{*} \\
(0.003) \\
\end{array}$ & $\begin{array}{l}-0.0522 * * * \\
(0.0112) \\
0.000554 \\
(0.00118) \\
\end{array}$ \\
\hline $\begin{array}{l}\mathrm{N} \\
\mathrm{R}^{2} \\
\text { F-statistic }\end{array}$ & $\begin{array}{l}2,204,800 \\
0.065 \\
10.15\end{array}$ & $\begin{array}{l}2,204,800 \\
0.064 \\
7.296\end{array}$ & $\begin{array}{l}2,204,800 \\
0.064 \\
8.55\end{array}$ \\
\hline
\end{tabular}




\section{APPENDIX 1}

This appendix presents a stylized model of how industry constraints and opportunities may affect the human capital distribution of who forms a spinout, or more generally, who engages in entrepreneurial activities. It is intended to provide additional insights into the intuition underlying the hypotheses tested in the paper.

\section{Individuals}

Individuals are assumed to vary along two dimensions known to them: their human capital $\theta \in(1, \infty)$ and their preference for entrepreneurial activity $\eta \in(1, \infty)$. We assume that these two variables are from distributions with pdfs $f($.$) and g($.$) respectively and are independently$ drawn of each other. We also assume that $f^{\prime}($.$) and g^{\prime}($.$) are negative throughout their$ support. In other words, we are broadly assuming that for any two levels of human capital,

$\theta>\dot{\theta}$, the 'number' of individuals with the lower level of human capital will be greater. A similar assumption is made about entrepreneurial preferences. Finally, all individuals have the same discount factor $\beta$.

For simplicity, we assume a linear utility function for individuals that depends on their (expected) wealth and their engaging in entrepreneurial activity, i.e., the utility of engaging in entrepreneurial activity, given a entrepreneurial preference $\eta$ is given by $u(w, \eta)=w+\eta$ where $w$ is the wealth generated from the entrepreneurial activity. If the individual does not pursue any entrepreneurial activity, their utility is simply equal to the wealth from their other activities including employment at their parent firm, say $w^{*}(\theta)$. In particular, we assume that $w^{*}(\theta)=w^{*}(0)+w \theta^{\alpha}, w^{*}(0)>0, \alpha \in(0,1)$. 


\section{New Venture Opportunities}

New ventures are founded by individuals. The quality of the idea is uncertain at the time of entry. Upon entry, individuals discover whether their new venture is 'good idea' or not. Higher human capital individuals are assumed to be more likely to face 'good ideas'. In particular, we assume that the probability of observing a 'good idea' is given by $\phi(\theta)=e^{1-\theta}\left(\phi_{0}-1\right)+1$ where $0 \leq \phi_{0}<1$, and is known to the individuals. Note that $\phi(1)>0$ and $\phi(\theta) \rightarrow 1$ as $\theta \rightarrow \infty$, and $\phi^{\prime}(\theta)>0$.

\section{New Venture Operations}

If entrepreneurs observe the new venture to be a 'good idea', they continue operations, and

remain as entrepreneurs for ever. Else, we assume that they exit immediately. If they continue, we assume that the cost function of the venture depends on individual human capital. In particular, we assume that new ventures have the following cost function. The underlying intuition is that individuals with greater human capital are likely to be better at managing their operations, which will then be reflected as lower costs.

$$
c(q, \theta)=\frac{q^{2}}{2 \delta \theta}
$$

where $\delta>1$ and represents the importance of human capital in determining the costs.

Further, we assume that these new ventures are price takers and face a price $p$ in their output markets. Given this, the optimal size of a venture is increasing in human capital, conditional on successful entry. Specifially, the optimal size is given by:

$$
q^{*}(\theta)=\delta \theta p
$$


Starting new ventures require an initial entry cost $s$, which becomes sunk on entry. Thus, the value of a successful new venture that are at the optimal size is given by:

$$
v^{*}(\theta)=\frac{\delta^{2} \theta p^{2}}{2(1-\beta)}-s
$$

\section{Capital Constraints}

Individuals face capital constraints, which are modeled as follows. Instead of paying the full sunk cost $s$, individuals can only pay a smaller sunk cost, $s_{0}$. This is assumed to give them a new venture with a size, conditional on being a 'good idea', equal to $q=z q^{u}$, $z \in[\underline{z}, 1), \underline{z}>0$. We assume that $z$ is constant for a given industry, i.e., all entrepreneurs face the same constraints. The value of a successful new venture started with capital constraints is then:

$$
v^{c}(\theta)=\frac{z \delta^{2} p^{2} \theta}{1-\beta}\left(1-\frac{z}{2}\right)-s_{0}
$$

We assume that $s_{0}$ is big enough relative to $s$ that no individual prefers the constrained option over the unconstrained one.

\section{Choice of Entrepreneurship}

Based on the above assumptions, individuals will start a new venture if the expected utility from starting the venture exceeds the utility from their outside option. Thus, an individual with parameters $(\theta, \eta)$ becomes an entrepreneur if:

$$
\phi(\theta) v^{c}(\theta)-(1-\phi(\theta)) s_{0}+\eta \geq w^{*}(\theta)
$$


This implies that for any given $\theta$, there is a threshold level of entrepreneurial preference $\eta$ such that everyone with the same $\theta$ and a higher entrepreneurial preference will engage in entrepreneurship. Substituting for $v^{c}(\theta)$, and rearranging, we get the threshold entrepreneurial preference as:

$$
\eta^{*}(\theta)=w^{*}(0)+w \theta^{\alpha}-\phi(\theta) \frac{z \delta^{2} p^{2} \theta}{1-\beta}\left(1-\frac{z}{2}\right)+s_{0}
$$

Note that given our assumptions, there will always be some individuals that satisfy the above condition. 11 To reduce notational clutter, we define $M(z, \delta)=\frac{z\left(1-\frac{z}{2}\right) \delta^{2} p^{2}}{1-\beta}$. Except where necessary, we simply use $M$ instead of $M(z, \delta)$. Then, the threshold entrepreneurial preference is given by:

$$
\eta^{*}(\theta)=w^{*}(0)+w \theta^{\alpha}-\phi(\theta) M \theta+s_{0}
$$

Therefore, $\frac{\partial \eta^{*}}{\partial \theta}$ is given by:

$$
\frac{\partial \eta^{*}}{\partial \theta}=\alpha w \theta^{\alpha-1}-\phi^{\prime}(\theta) M \theta-M \phi(\theta)
$$

Substituting for $\phi(\theta)$ and $\phi^{\prime}(\theta)$ and simplifying, we get:

$$
\frac{\partial \eta^{*}}{\partial \theta}=\alpha w \theta^{\alpha-1}+\left(\phi_{0}-1\right) e^{1-\theta} M(\theta-1)-M
$$

The above expression could be positive or negative depending on the parameters. To derive our hypothesis, we assume the following: Assumption 1. $\alpha w<M(\underline{z}, 1)$. Given Assumption $1, \phi_{0}<1$, and $\theta>1$, it follows that the right hand side of 9 is always negative for all $\theta$. This implies that the entrepreneurial preference threshold declines as the level of individual human capital increases.

\footnotetext{
${ }^{1}$ However, it is possible that the right hand side of the above condition is negative for some $\theta$, and hence, all individuals with that $\theta$ engage in entrepreneurship.
} 


\section{Probability of Founding and Industry Contexts}

The probability of founding a new venture for any given $\theta$ is given by:

$$
\rho(\theta)=\int_{\eta^{*}(\theta)}^{\infty} g(\eta) d \eta
$$

Our primary interest is in examining how the relationship between the probability of founding and human capital varies across industry contexts. That is, we want to investigate how $\frac{\partial \rho}{\partial \theta}$ varies with other industry variables such as $z, \delta$, and $\phi_{0}$.

Using 10, we obtain:

$$
\frac{\partial \rho}{\partial \theta}=-g\left(\eta^{*}\right) \frac{\partial \eta^{*}}{\partial \theta}
$$

Since $\frac{\partial \eta^{*}}{\partial \theta}$ is always negative, it follows from above that $\frac{\partial \rho}{\partial \theta}$ is always positive. Thus, the probability of founding is increasing in individual human capital.

\section{Probability of Founding and Industry Contexts}

Now we examine how the probability of founding varies with different industry contexts.

\section{Probability of Founding and Capital Constraints (Hypothesis 2)}

As the intensity of capital constraints increase, $z$ decreases. That is, for a given capital, entrepreneurs are constrained to start a smaller venture relative to optimal size. Differentiating 11 w.r.t $z$, we get:

$$
\frac{\partial}{\partial z} \frac{\partial \rho}{\partial \theta}=-\frac{\partial g\left(\eta^{*}\right)}{\partial z} \frac{\partial \eta^{*}}{\partial \theta}-g\left(\eta^{*}\right) \frac{\partial}{\partial z} \frac{\partial \eta^{*}}{\partial \theta}
$$


Consider $\frac{\partial g\left(\eta^{*}\right)}{\partial z}=\frac{\partial g\left(\eta^{*}\right)}{\partial \eta^{*}} \frac{\partial \eta^{*}}{\partial z}$.

The first term is negative since $g($.$) is decreasing in its argument. The second term is$

$$
\frac{\partial \eta^{*}}{\partial z}=-\theta \phi(\theta) \frac{\partial M}{\partial z}
$$

Since $\frac{\partial M}{\partial z}$ is positive, $\frac{\partial \eta^{*}}{\partial z}$ must be negative. Together, these imply that $\frac{\partial g\left(\eta^{*}\right)}{\partial z}$ is positive. This implies that $\frac{\partial g\left(\eta^{*}\right)}{\partial z} \frac{\partial \eta^{*}}{\partial \theta}$ is negative.

Now, consider

$$
\frac{\partial}{\partial z} \frac{\partial \eta^{*}}{\partial \theta}=\left(\phi_{0}-1\right) e^{1-\theta}(\theta-1) \frac{\partial M}{\partial z}-\frac{\partial M}{\partial z}
$$

This is negative since $p h i_{0}<1$ and $\frac{\partial M}{\partial z}>0$. Thus, this implies that $\frac{\partial}{\partial z} \frac{\partial \rho}{\partial \theta}$ is positive.

This implies that as capital constraints decrease, $\frac{\partial \rho}{\partial \theta}$ increases. Therefore, as capital constraints decrease, the relative propensity of high human capital individuals to start a new venture increases.

\section{Probability of Founding and Importance of Human Capital (Hypothesis 3)}

As the importance of human capital in an industry increases, $\delta$ increases. Therefore,

$$
\frac{\partial}{\partial \delta} \frac{\partial \rho}{\partial \theta}=-\frac{\partial g\left(\eta^{*}\right)}{\partial \delta} \frac{\partial \eta^{*}}{\partial \theta}-g\left(\eta^{*}\right) \frac{\partial}{\partial \delta} \frac{\partial \eta^{*}}{\partial \theta}
$$

Using arguments similar to those in the above subsection on capital constraints, it can be

shown that $\frac{\partial}{\partial \delta} \frac{\partial \rho}{\partial \theta}>0$. Therefore, the relative propensity of high human capital individuals to start a new venture increases. 


\section{Probability of Founding and Industry Opportunities (Hypothesis 4)}

We model the extent of industry opportunities increasing as an increase in $\phi_{0}$. Therefore:

$$
\frac{\partial}{\partial \phi_{0}} \frac{\partial \rho}{\partial \theta}=-\frac{\partial g\left(\eta^{*}\right)}{\partial \phi_{0}} \frac{\partial \eta^{*}}{\partial \theta}-g\left(\eta^{*}\right) \frac{\partial}{\partial \phi_{0}} \frac{\partial \eta^{*}}{\partial \theta}
$$

Using arguments similar to those in the above subsection on capital constraints, it can be

shown that $\frac{\partial}{\partial \phi_{0}} \frac{\partial \rho}{\partial \theta}<0$. Therefore, as the extent of opportunities in an industry increase, the relative propensity of high human capital individuals to start a new venture decreases. 